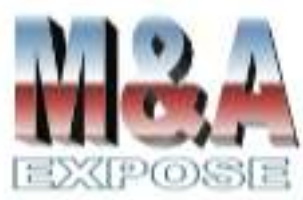

http://jurnal.usahid.ac.id/index .php/accounting
${ }^{1}$ Fakultas Ekonomi Universitas Islam Sultan Agung Semarang winarsih@unissula.ac.id

\section{Religiusitas Auditor Terhadap Kualitas Auditor Eksternal dengan Independensi dan Profesionalisme Auditor sebagai Variabel Mediasi}

\author{
Winarsih $^{1}$
}

\section{Abstrak}

Penelitian ini bertujuan menguji pengaruh religiusitas auditor terhadap kualitas audit dengan independensi dan profesionalisme sebagai variabel mediasi. Obyek penelitian adalah KAP di Kota Semarang dengan purposive sampling auditor minimal berpengalaman tiga tahun. Jumlah data observasi sebanyak 40 . Hasil penelitian menunjukkan bahwa profesionalisme dan independensi berpengaruh langsung terhadap kualitas audit, sedangkan religiusitas tidak berpengaruh terhadap kualitas audit dan independensi auditor, namun berpengaruh terhadap profesionalisme auditor. Demikian pula profesionalisme auditor tidak berpengaruh terhadap independensi auditor. Pengaruh tidak langsung menunjukkan bahwa religiusitas auditor melalui profesionalisme auditor berpengaruh positif signifikan terhadap kualitas audit. Hal ini mengindikasikan tingginya religiusitas auditor melalui profesionalme auditor akan menghasilkan audit yang berkualitas.

Kata kunci : independensi, kualitas audit, profesionalisme, religiusitas.

\section{Abstract}

This study aimed to analyze the effect of auditor's religiousity toward audit's quality with auditor's independence and profesionalism as a mediating variable. The object of this research was KAP Office in the Semarang City. We used purposive sampling method with the criteria of three years minimum of working experience in an auditing team. There were 40 data being observed. The result showed that the profesionalism and indepence had positive effect on quality of audit. Auditor's profesionalism had no effect on independence. Religiousity were found not to have any effect on audit's quality and auditor's independence, but it had effect on profesionalism. Auditor's religiousity, through profesionalism, would have positive effect on audit's quality. This indicates that a higher level of profesionalism and independence should create a better quality audit. Whereas religiousity of the auditor, through its effect on profesionalism, should create a better quality of audit.

Keywords : independence, quality of audit, profesionalism, religiousity. 


\section{PENDAHULUAN}

Audit merupakan proses pemeriksaan yang sistematis yang bersifat objektif dan independen dalam rangka untuk mengumpulkan dan mengevaluasi bukti-bukti yang telah dikumpulkan. Selain itu, apakah pernyataan dan pelaporan yang dibuat telah sesuai dengan kenyataan atau tidak. Pengguna laporan keuangan yang telah diaudit oleh akuntan publik apakah dapat dipercaya kebenarannya untuk dijadikan sebagai dasar pengambilan keputusan dan telah sesuai dengan prinsip-prinsip akuntansi yang berlaku di Indonesia. Oleh karena itu dalam rangka untuk menilai kewajaran laporan keuangan yang disajikan oleh manajemen maka diperlukan jasa akuntan publik atau auditor, yang melakukan pemeriksaan atau mengaudit terhadap laporan keuangan klien berdasarkan penugasan atau perikatan antara klien dengan akuntan publik.

Keberadaan auditor pada suatu entitas sebagai pendeteksi kejanggalan-kejanggalan dalam laporan keuangan klien, diharapkan mampu mengemukakan kecurangan yang mungkin dilakukan oleh pihak manajemen dan menghindarkan principal dari kerugiaan sebagai pihak pemilik. Masalah keagenan auditor bersumber dari adanya mekanisme kelembagaan antara auditor dan manajemen. Di satu sisi auditor ditunjuk manajemen untuk melakukan audit, namun di sisi lain, jasa audit dibayar dan ditanggung manajemen. Mekanisme kelembagaan inilah yang mengakibatkan munculnya keterikatan auditor pada klien sehingga dapat berimbas terhadap kualitas audit.

Profesi akuntan publik merupakan profesi kepercayaan masyarakat sehingga dalam melaksanakan tugas auditnya harus berpedoman pada standar audit yang ditetapkan oleh Ikatan Akuntan Indonesia (IAI). Standar yang mengatur pelaksanaan audit di Indonesia adalah Standar Profesional Akuntan Publik (SPAP). Selain itu, berpegang pada Standar Auditing yang meliputi tiga hal, yaitu : (SA Seksi 150 SPAP, 2001): 1).Audit harus dilaksanakan oleh seorang atau lebih yang memiliki keahlian dan pelatihan teknis yang cukup,2).Dalam semua hal yang berhubungan dengan perikatan, independensi dalam sikap mental harus dipertahankan oleh auditor,3). Dalam pelaksanaan audit dan penyusunan laporannya, auditor wajib menggunakan kemahiran profesionalnya (kompetensinya) dengan cermat dan seksama. Namun permasalahan yang muncul adalah masih terdapat rendahnya kualitas audit karena adanya keterlibatan akuntan publik didalamnya.

Watts and Zimmerman (1981) mengatakan bahwa bagi laporan audit yang mempunyai nilai bagi pengguna laporan keuangan, ada kemungkinan bahwa auditor akan menemukan pelanggaran dan melaporkan pelanggaran yang ditemukan. Independensi adalah sikap yang diharapkan dari seorang akuntan publik untuk tidak mempunyai keinginan pribadi dalam melaksanakan tugasnya yang bertentangan dengan prinsip integritas dan obyektifitas (Kode Etik Akuntan, 1994). Dengan demikian independensi auditor merupakan kejujuran seorang akuntan dalam mempertimbangkan fakta-fakta yang bersifat objektif dan tidak memihak terhadap siapapun dalam merumuskan dan menyatakan pendapat. Apabila seorang auditor memiliki independensi maka kualitas auditor akan tercapai.

Masyarakat berasumsi bahwa auditor yang berlatar belakang religius atau agamis dapat menciptakan suatu penghalang bagi hilangnya independensi. Oleh karena itu, religiusitas dapat meningkatkan kualitas audit, karena religiusitas auditor cenderung berasal dari komitment dalam ajaran Islam. Dan bukan hanya terjadi ketika seseorang melakukan ibadah ritual saja, melainkan juga ketika melakukan aktivitas lainnya sehari-hari. Keberagamaan (religiusitas) diwujudkan dalam berbagai sisi kehidupan manusia (Maryani \& 
Ludigdo, 2002). Dalam matlamat pertama etika Islam adalah supaya manusia mempuyai perilaku yang baik mengikuti ajaran Islam bagi mencapai keridhoan Allah. Agama mempunyai pengaruh dalam pembentukan sikap karena agama meletakkan dasar konsep moral dalam diri individu.

Masyarakat mempercayai bahwa laporan keuangan yang dihasilkan adalah dari auditor yang profesionalnya dalam proses pelaksanaan audit dan sikap profesionalnya harus tetap terjaga selama proses pemeriksaan. Apabila auditor tidak mampu mempertahankan sikap profesionalnya, maka laporan keuangan yang diaudit tidak dapat dipercaya lagi, dan memungkinkan adanya litigasi paska audit. Penelitian ini mencoba mengevaluasi tentang pengaruh langsung dan tidak langsung dari variabel religiusitas auditor terhadap kualitas audit, melalui profesionalitas dan independensi auditor.

Berdasarkan latar belakang tersebut, maka rumusan penelitian ini adalah 1). Apakah religiusitas auditor berpengaruh terhadap profesional auditor? 2). Apakah religiusitas auditor berpengaruh terhadap independensi auditor? 3). Apakah profesionalisme berpengaruh terhadap independensi auditor? 4) Apakah religiusitas auditor, profesional dan independensi berpengaruh terhadap kualitas audit? 5). Apakah profesionalisme berpengaruh terhadap kualitas audit? 6). Apakah independensi berpengaruh terhadap kualitas audit ? 7). Apakah profesionalisme dan independensi auditor memediasi hubungan religiusitas terhadap kualitas audit ? Sehubungan dengan rumusan masalah yang tersebut, maka tujuan dari penelitian ini adalah: 1). Untuk menganalisis pengaruh dari religiusitas auditor terhadap profesionalisme auditor 2). Untuk menganalisis pengaruh dari religiusitas auditor terhadap independensi auditor 3). Untuk menganalisis pengaruh profesionalisme terhadap independensi 4) Untuk menganalisis pengaruh religiusitas auditor terhadap kualitas audit. 5) Untuk menganalisis pengaruh profesionalisme auditor terhadap kualitas audit, 6) Untuk menganalisis pengaruh independensi auditor terhadap kualitas audit, 7). Untuk menganalisis apakah profesionalisme dan independensi memediasi hubungan religiusitas terhadap kualitas audit

\section{TINJAUAN PUSTAKA}

Agency Theory menjelaskan adanya konflik antara manajemen selaku agen dengan pemilik selaku principal. Principal ingin mengetahui segala informasi termasuk aktivitas manajemen, yang terkait dengan investasi atau dananya dalam perusahaan. Teori keagenan membantu auditor sebagai pihak ketiga untuk memahami konflik kepentingan yang dapat muncul antara principal dan agen atau konflik yang terjadi antara pemberi tugas dengan auditor. Principal selaku investor bekerjasama dan menandatangani kontrak kerja dengan agen atau manajemen perusahaan untuk menginvestasikan keuangan mereka. Dengan adanya auditor yang independen diharapkan tidak terjadi kecurangan dalam laporan keuangan yang dibuat oleh manajemen.

Kualitas audit merupakan hal penting yang harus diperhatikan oleh para auditor dalam proses pengauditan karena auditor akan memberikan penemuan mengenai suatu penyimpangan dalam sistem akuntansi klien dan dalam hal pencatatannya. Seorang auditor akan melaporkan adanya laporan yang salah saji telah dideteksi dan didefinisikan sebagai independensi auditor. Oleh karena itu, seorang auditor dituntut untuk menghasilkan kualitas pekerjaan yang tinggi, karena auditor mempunyai tanggung jawab yang besar terhadap pihak - pihak yang berkepentingan atas laporan keuangan suatu perusahaan. Terdapat lima 
indicator yang digunakan untuk kualitas audit yaitu (1) melaporkan kesalahan instansi, (2) sistem akuntansi instansi, (3) komitmen yang kuat, (4) pekerjaan lapangan tidak mudah percaya dengan pernyataan klien, (5) pengambilan keputusan.

Religiusitas merupakan landasan dimiliki seseorang dalam berkomitmen mendasarkan pada ajaran agama yang dianut dalam hal berperilaku sebagai individu, bertindak dan bersikap. Berdasarkan pendapat Weaver dan Agle, 2002 dalam Hutahahean \&Hasnawati, 2015 menyatakan bahwa religiusitas memiliki pengaruh terhadap perilaku dan sikap seseorang. Seorang auditor yang memiliki religiusitas yang tinggi cenderung akan membuat judgment yang dapat dipertanggungjawabkan sehingga audit yang dilakukan akan lebih berkualitas. Indikator yang digunakan dalam penelitian ini mengacu kuesioner penelitian (Hastuti, 2014) yaitu dengan indikator (1) Keterlibatan Ritual, (2) Keterlibatan Ideologis, (3) Keterlibatan Intelektual, (4) Keterlibatan Experiental, (5) Keterlibatan Penghayatan

Menurut Kasim, et al (2013:224) indepedensi adalah sikap seseorang dimana dalam sudut pandang, pendapat, maupun kesimpulan yang disampaikannya tidak bergantung pada pengaruh dan tekanan dari pihak yang berkepentingan. Sikap independen ini adalah sikap mental yang dimiliki auditor untuk tidak memihak dalam melakukan audit, karena auditor melaksanakan pekerjaannya untuk kepentingan umum. Auditor harus bebas dari masalah benturan kepentingan (conflict of interest) dan tidak boleh membiarkan faktor salah saji material (material misstatement) yang diketahuinya atau mengalihkan pertimbangannya kepada pihak lain. Dengan demikian seorang auditor tidak dibenarkan memihak kepada kepentingan siapapun dan jika auditor tersebut memihak pada salah satu kepentingan maka dia tidak bisa mempertahankan kebebasan pendapatnya, karena akan kehilangan sikap tidak memihak, berarti auditor tersebut tidak memiliki sikap mental independen.

Profesionalisme Auditor adalah sikap dan perilaku auditor dalam menjalankan profesinya dengan kesungguhan dan tanggung jawab agar mencapai kinerja tugas sebagaimana yang diatur oleh organisasi profesi, meliputi pengabdian pada profesi, kewajiban sosial, kemandirian, keyakinan profesi dan hubungan dengan rekan seprofesi. Profesionalisme auditor dapat dipengaruhioleh kondisi keuangan klien, karena dengan kondisi keuangan yang baik, maka dapat memberikan fee audit yang besar dan memberikan fasilitas-fasilitas sehingga dapat mempengaruhi kinerja dan profesionalisme auditor dalam menjalankan tugasnya. Dalam penelitian ini Profesionalisme diukur dengan indikator yang mengacu penelitian (Nugrahini, 2015) yaitu (1) pengabdian pada profesi, (2) kewajiban sosial, (3) kemandirian, kenyakinan terhadap peraturan profesi dan (4) hubungan dengan sesama profesi.

Auditor yang profesional berarti bertanggung jawab untuk berperilaku yang lebih dari sekedar memenuhi tanggung jawab yang dibebankan kepadanya. Seorang auditor dikatakan profesional apabila memiliki pendidikan dan pengalaman berpraktik sebagai auditor independent dan akan membuat judgment yang dapat dipertanggungjawabkan di dunia maupun akhirat. Banyaknya kasus penyimpangan yang dilakukan oleh auditor salah satunya disebabkan oleh kurangnya sikap religiusitas yang dimiliki. Seseorang yang memiliki sikap religiusitas yang tinggi akan berusaha menjalankan segala perintah Tuhannya dan menjauhi segala larangan-Nya, sehingga seorang auditor akan bertindak secara profesional. Oleh karena itu auditor yang profesional dapat dicapai apabila auditor memiliki tingkat religiusitas yang baik.

H1: Religiusitas berpengaruh positif terhadap profesionalisme auditor 
Independensi merupakan suatu standar auditing yang penting karena opini akuntan independen menyangkut kredibilitas laporan keuangan yang disajikan oleh manajemen. Oleh karena itu sikap independen mutlak dimiliki oleh auditor dalam menjalankan penugasan auditnya. Sikap independen ini adalah sikap mental yang dimiliki auditor untuk tidak memihak dalam melakukan audit, karena auditor melaksanakan pekerjaannya untuk kepentingan umum. Seorang auditor dikatakan independen apabila tidak bergantung pada pengaruh dan tekanan dari pihak yang berkepentingan. Seorang auditor yang memiliki religiusitas yang tinggi cenderung jujur atau fairness, karena sebagai auditor tidak hanya kepada manajemen klien dan pemilik perusahaan klien saja tetapi juga bertanggung jawab terhadap kreditur, investor dan masyarakat. Apabila auditor kehilangan sikap independensinya maka masyarakat tidak lagi percaya pada profesi akuntan publik.

H2: Religiusitas berpengaruh positif terhadap independensi auditor

Profesionalisme merupakan individual seseorang yang penting dengan tidak melihat pekerjaan tersebut dengan adanya tanggung jawab terhadap masyarakat, klien maupun rekan seprofesi, seorang akuntan publik yang profesional harus bersikap semestinya. Seseorang dikatakan profesional jika mempunyai keahlian untuk melaksanakan tugas sesuai dengan bidangnya, menetapkan standar baku di bidang profesi yang bersangkutan dan menjalankan tugas profesinya dengan mematuhi etika profesi yang telah ditetapkan. Sedangkan independensi merupakan sikap auditor untuk tidak mempunyai kepentingan pribadi dalam pelaksanaan tugasnya, yang bertentangan dengan prinsip integritas dan obyektivitas. Auditor tidak dibenarkan memihak kepada kepentingan siapa pun, dan mempertahankan kebebasan pendapatnya yang tidak dipengaruhioleh tekanan klien. Dengan demikian, seorang auditor yang independen sangat dipengaruhi oleh profesionalisme auditor

H3: Profesionalisme auditor berpengaruh positif terhadap independensi auditor

Kualitas audit dapat diartikan sebagai bagus tidaknya suatu pemeriksaan yang telah dilakukan oleh auditor. Seorang auditor yang memiliki sikap religiusitas yang tinggi diharapkan akan menghasilkan kualitas audit yang baik. Religiusitas dapat diketahui melalui aspek keyakinan, ketaatan, penghayatan, pengetahuan dan pelaksanaan terhadap ajaran agama dan adanya pengamalan terhadap nilai-nilai tersebut. Semakin tinggi tingkat religiusitas seseorang maka akan semakin rendah kecenderungan kecurangan akuntansi. Hal ini sesuai dengan hasil penelitian yang dilakukan oleh Hastuti (2014), bahwa religiusitas auditor berpengaruh positif terhadap kualitas audit. Selain itu, hasil penelitian Barnett, Bass dan Brown (1996) dalam (Pamungkas, 2014) menunjukkan bahwa religiusitas mempengaruhi standar moral seseorang, serta religiusitas akan memberikan kontribusi terhadap idealisme seseorang. Dengan demikian kualitas audit dapat dicapai apabila auditor memiliki tingkat religiusitas yang baik.

H4 : Religiusitas auditor berpengaruh positif terhadap kualitas audit

Auditor yang profesional menjadi syarat utama sebagai auditor, mengacu pada kemampuan dan perilaku profesional. Auditor dikatakan profesional apabila berpegang teguh terhadap sikap dalam menjalankan tanggungjawab profesi secara profesional sehingga akan berdampak terhadap kualitas audit. Apabila seorang auditor memiliki kemampuan namun tidak memiliki perilaku profesional maka kemampuan yang dimiliki akan di salah gunakan dan berpotensi melakukan penyimpangan Hal ini bisa terjadi karena tidak teguh terhadap sikap dalam menjalankan tanggungjawab profesi, sehingga profesionalisme 
auditor sangat berpengaruh terhadap kualitas audit yang dilakukan oleh auditor independen dalam melakukan tugas dan tanggungjawabnya.

H5: Profesionalisme auditor berpengaruh positif terhadap kualitas audit

Independensi auditor merupakan salah satu faktor yang penting untuk menghasilkan audit yang berkualitas. Adapun tingkat independensi merupakan faktor yang menentukan dari kualitas audit. Adanya sikap independensi maka auditor dapat melaporkan jika terjadi penyimpangan dalam laporan keuangan klien. Dengan demikian dapat dikatakan semakin tinggi tingkat independensi seorang auditor maka akan semakin tinggi pula kualitas audit yang dihasilkan.

H6: Independensi auditor berpengaruh positif terhadap kualitas audit

Kualitas audit merupakan hal yang penting dalam mempertahankan proses audit yang dimiliki oleh para auditor. Seorang auditor independen dalam menjalankan tugasnya harus memegang prinsip profesi. Jika auditor memiliki religiusitas yang tinggi maka akan membuat judgment yang dapat dipertanggungjawabkan hasilnya. Peneliti meyakini bahwa adanya auditor yang profesional dan bersifat independen, maka kualitas audit akan meningkat.

$\mathrm{H} 7$ : Profesionalisme dan independensi auditor memediasi hubungan religiusitas auditor dengan kualitas audit

Berdasarkan tinjauan pustaka tersebut, berikut adalah model penelitian yang digunakan :

Gambar 1

Kerangka Penelitian

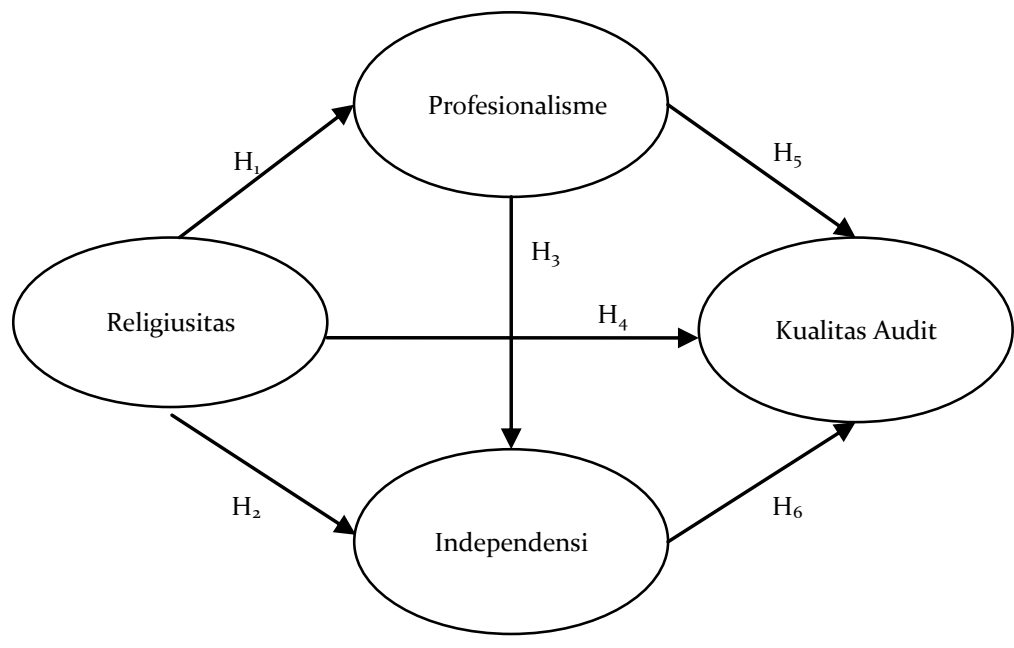

METODE PENELITIAN

Jenis penelitian yang digunakan adalah kuantitatif. Populasi dalam penelitian ini adalah auditor yang ada di KAP di kota Semarang. Pemilihan populasi di kota Semarang karena kota Semarang termasuk kota besar di Jawa Tengah yang sudah banyak KAP besar maupun kecil, sehingga menuntut eksistensi auditor independen dalam melakukan pemeriksaan terhadap laporan keuangan. 
Teknik yang digunakan untuk penentuan sampel adalah purposive sampling, dengan mendasarkan pada kriteria auditor telah mengikuti pendidikan dan pelatihan sebagai auditor, serta telah memenuhi masa kerja minimum tiga tahun dalam sebuah tim audit. Data yang digunakan dalam penelitian ini berupa data primer, yang diperoleh secara langsung dari auditor yang ada di KAP di kota Semarang sebanyak 40 responden. Data yang terkumpul discreening untuk memilah data yang dapat digunakan dan data yang tidak dapat digunakan. Setelah dipilah, untuk mengolah data penelitian menggunakan SPSS versi 19

Uji validitas dilakukan untuk mengetahui sejauh mana ketepatan dan kecermatan suatu alat ukur dapat mengukur suatu konstruk. Instrumen yang valid berarti instrumen tersebut mampu mengukur tentang apa yang diukur. Uji reliabilitas digunakan untuk mengukur apakah suatu instrumen merupakan indikator dari variabel atau konstruk. Instrumen yang memenuhi persyaratan reliabilitas adalah instrumen yang menghasilkan ukuran yang konsisten dari waktu ke waktu, walaupun instrumen tersebut digunakan untuk berkali-kali.

Variabel dependen yaitu kualitas audit $(\mathrm{Y})$ adalah pelaksanaan audit yang dilakukan sesuai standar. sehingga auditor mampu mengungkapkan dan melaporkan apabila terjadi pelanggaran yang dilakukan klien. Indikator kualitas audit mengacu pada kuesioner yang digunakan oleh Tjun, Marpaung, \& Setiawan (2012) yaitu (1) melaporkan kesalahan instansi, (2) sistem akuntansi instansi, (3) komitmen yang kuat, (4) pekerjaan lapangan tidak mudah percaya dengan pernyataan klien, (5) pengambilan Keputusan

Variabel independen adalah religiusitas auditor (X1), sejauh mana seorang auditor berkomitmen untuk agama dan ajaran - ajaran yang ada di dalamnya, termasuk komitmen yang berpatokan pada agama terhadap sikap dan perilaku individu (Johnson et al, 2001 dalam (Hutahahean \& Hasnawati, 2015). Indikator yang digunakan dalam penelitian ini mengacu kuesioner penelitian (Hastuti, 2014) yaitu dengan indikator (1) Keterlibatan Ritual, (2) Keterlibatan Ideologis, (3) Keterlibatan Intelektual, (4) Keterlibatan Experiental, (5) Keterlibatab Penghayatan.

Variabel mediating yang digunakan adalah profesionalisme dan independensi auditor. Profesionalisme auditor adalah sikap dan perilaku auditor dalam menjalankan profesinya dengan kesungguhan dan tanggung jawab agar mencapai kinerja tugas sebagaimana yang diatur oleh organisasi profesi, meliputi pengabdian pada profesi, kewajiban sosial, kemandirian, keyakinan profesi dan hubungan dengan rekan seprofesi. Dalam penelitian ini Profesionalisme auditor diukur dengan indikator yang mengacu penelitian (Nugrahini, 2015) yaitu (1) pengabdian pada profesi, (2) kewajiban sosial, (3) kemandirian, kenyakinan terhadap peraturan profesi dan (4) hubungan dengan sesama profesi. Sedangkan independensi merujuk pada kejujuran dalam diri auditor dalam mempertimbangkan fakta dan adanya pertimbangan yang objektif yang tidak memihak dalam diri auditor dalam merumuskan dan menyatakan pendapatnya. Indikator yang disajikan sebagai bahan indikator untuk kualitas audit mengacu kuesioner penelitian (Tjun, Marpaung, \& Setiawan, 2012) yaitu (1) Lama hubungan dengan klien (Audit Tenure), (2) Tekanan dari klien, (3) Telaah dari rekan auditor (Peer Review), dan (4) Jasa Non Audit.

Analisis Regresi Berganda dilakukan atas tiga model berikut :

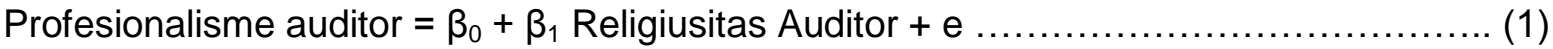

Independensi auditor $=\beta_{0}+\beta_{1}$ Religiusitas Auditor $+\beta_{2}$ Profesionalisme Auditor + e ........(2)

Kualitas Audit $=\beta_{0}+\beta_{1}$ Religiusitas Auditor $+\beta_{2}$ Profesionalisme Auditor +

$\beta_{3}$ Independensi Auditor $+e$ 


\section{HASIL DAN PEMBAHASAN}

Berdasarkan uji validitas, semua indikator dari keseluruhan variabel mempunyai nilai sig< $\alpha(0,05)$ sehingga dapat dikatakan bahwa keseluruhan indikator dari keseluruhan variabel adalah valid. Berdasarkan hasil pengujian reliabilitas dapat diketahui bahwa nilai cronbach alpha dari variabel kualitas audit sebesar 0,737, religiusitas auditor sebesar 0,926, profesionalisme auditor sebesar 0, 941 dan independensi auditor sebesar 0,963, sehingga semua variabel penelitian memiliki nilai Cronbach's Alpha lebih besar dari 0,60. Dengan demikian variabel yang digunakan dalam penelitian ini dikatakan reliable.

Berdasarkan hasil pengujian normalitas untuk variabel religiusitas terhadap profesionalisme auditor menunjukkan bahwa asumsi normalitas terpenuhi ( $p$-Value uji Kolmogorov Smirnov sebesar 0,227 ). Untuk variabel religiusitas dan profesionalisme auditor terhadap kualitas audit terpenuhi, karena p-Value uji Kolmogorov Smirnov sebesar 0,109. Sedangkan untuk variabel religiusitas, profesionalisme, independensi terhadap kualitas audit asumsi normalitas terpenuhi, hasil perhitungan menunjukkan $p$-Value uji Kolmogorov Smirnov sebesar 0,999 .

Asumsi tidak terjadi heteroskedastisitas untuk variabel religiusitas terhadap profesionalisme auditor terpenuhi dengan hasil uji Glejser tidak signifikan, yaitu $p$-value = 0,504 . Demikian pula untuk variabel religiusitas dan profesionalisme auditor terhadap kualitas audit tidak terjadi heteroskedastistias, sehingga asumsi ini terpenuhi dengan hasil uji Glejser tidak ada yang signifikan, yaitu $p$-value $=0,860$ dan 0,145 . Selanjutnya untuk variabel religiusitas, profesionalisme, independensi terhadap kualitas audit asumsi tidak terjadi heteroskedastisitas : terpenuhi. Profesionalisme Auditor dan Independensi Auditor, hasilnya yaitu dengan $p$-value $=0,919$ dan 0,338 . Tetapi terjadi heteroskedastistias pada variabel religiusitas ( $p$-value $=0,034$ ).

Asumsi tidak terjadi multikolinieritas untuk variabel religiusitas dan profesionalisme auditor terhadap kualitas terpenuhi (karena semua nilai Tolerance $>0,1$; atau semua nilai VIF < 10). Untuk variabel religiusitas, profesionalisme, independensi terhadap kualitas audit asumsi tidak terjadi multikolinieritas: terpenuhi karena semua nilai Tolerance $>0,1$; atau semua nilai VIF $<10)$.

Uji fit model (Uji F) untuk variabel variabel religiusitas terhadap profesionalisme auditor menunjukkan hasil $p$-value Uji $F=0,018$ (signifikan). Dengan demikian fit model bisa diterima. Untuk variabel religiusitas dan profesionalisme auditor terhadap kualitas audit menunjukkan hasil Uji fit model (Uji F) dengan p-value Uji F sebesar 0,195 , artinya tidak signifikan. Dengan demikian fit model tidak bisa diterima atau model tidak fit. Untuk variabel religiusitas dan profesionalisme auditor terhadap kualitas audit menunjukkan hasil $p$-value Uji F sebesar 0,000, signifikan. Artinya fit model bisa diterima.

Ukuran fit model dengan menggunakan Adjusted $R^{2}$ untuk variabel religiusitas terhadap profesionalisme auditor sebesar 0,117 , dalam kategori cukup, karena kemampuan menjelaskan hanya $11,7 \%$. Sedangkan sisanya sebesar $88,3 \%$ dijelaskan oleh variabel lain di luar penelitian ini. Untuk variabel religiusitas dan profesionalisme auditor terhadap kualitas audit menunjukkan ukuran fit model dengan nilai Adjusted $\mathrm{R}^{2}$ sebesar 0,035 , artinya model tersebut buruk, karena kemampuan menjelaskan hanya sebesar 3,5\%. Selanjutnya, untuk variabel religiusitas dan profesionalisme auditor terhadap kualitas audit Adjusted $R^{2}$ sebesar 0,612 , artinya model penelitian tersebut baik, karena kemampuan menjelaskan sebesar $61,2 \%$. 
Tabel 1 : Pengaruh Religiusitas terhadap Profesionalisme Auditor

\begin{tabular}{|c|c|c|c|c|c|c|}
\hline & \multirow[t]{2}{*}{ Model } & \multicolumn{2}{|c|}{ Unstandardized Coefficients } & \multirow{2}{*}{$\begin{array}{l}\text { Standardized } \\
\text { Coefficients }\end{array}$} & \multirow[t]{2}{*}{$t$} & \multirow[t]{2}{*}{ Sig. } \\
\hline & & $\mathrm{B}$ & Std. Error & & & \\
\hline 1 & $\begin{array}{l}\text { (Constant) } \\
\text { Religiusitas Auditor }\end{array}$ & $\begin{array}{r}2,036 \\
, 423 \\
\end{array}$ & $\begin{array}{l}, 670 \\
, 170 \\
\end{array}$ & ,373 & $\begin{array}{l}3,040 \\
2,481 \\
\end{array}$ & $\begin{array}{l}, 004 \\
, 018 \\
\end{array}$ \\
\hline
\end{tabular}

a. Dependent Variable : Profesionalisme Auditor

Profesionalisme Auditor $=0,423$ Religiusitas Auditor $+\mathrm{e}$

Tabel 2 : Pengaruh Religiusitas, Profesionalisme Terhadap Independensi Audititor

\begin{tabular}{|c|c|c|c|c|c|c|}
\hline & \multirow[t]{2}{*}{ Model } & \multicolumn{2}{|c|}{ Unstandardized Coefficients } & $\begin{array}{l}\text { Standardized } \\
\text { Coefficients }\end{array}$ & \multirow[t]{2}{*}{$\mathrm{t}$} & \multirow[t]{2}{*}{ Sig. } \\
\hline & & B & Std. Error & Beta & & \\
\hline \multirow{3}{*}{1} & (Constant) & 2,213 & ,868 & & 2,548 &, 015 \\
\hline & Religiusitas Auditor & 289 & 214 & 230 & 1,355 & 184 \\
\hline & Profesionalisme Auditor &, 124 & 189 &, 112 & 660 &, 514 \\
\hline
\end{tabular}

a. Dependent Variable : Independensi Auditor

Independensi Auditor $=2,213+0,289$ Religiusitas Auditor+0,124 Profesionalisme Auditor+e

Tabel 3 : Pengaruh Religiusitas, Profesionalisme dan Independensi terhadap Kualitas Audit

\begin{tabular}{|c|c|c|c|c|c|c|}
\hline & \multirow[t]{2}{*}{ Model } & \multicolumn{2}{|c|}{ Unstandardized Coefficients } & $\begin{array}{l}\text { Standardized } \\
\text { Coefficients }\end{array}$ & \multirow[t]{2}{*}{$\mathrm{t}$} & \multirow[t]{2}{*}{ Sig. } \\
\hline & & B & Std. Error & Beta & & \\
\hline \multirow{4}{*}{1} & (Constant) & 1,459 & ,371 & & 3,931 &, 000 \\
\hline & Religiusitas Auditor & 171 & 086 & ,219 & 1,986 & 055 \\
\hline & Profesionalisme Auditor & 320 & 075 & ,462 & 4,277 &, 000 \\
\hline & Independensi Auditor & ,262 & ,065 & 422 & 4,047 &, 000 \\
\hline
\end{tabular}

a. Dependent Variable : Kualitas Audit

Kualitas Audit $=1,459+0,171$ Religiusitas Auditor + 0,320 Profesionalisme Auditor $+0,262$ Independensi Auditor + e

Tabel 4 : Hasil Pengujian Hipotesis Pengaruh Langsung (Direct Effect)

\begin{tabular}{lccccccc}
\hline $\begin{array}{c}\text { Variabel } \\
\text { Independen }\end{array}$ & $\begin{array}{c}\text { Variabel } \\
\text { Dependen }\end{array}$ & Hipotesis & Arah & $\begin{array}{c}\text { Besar } \\
\text { Pengaruh }\end{array}$ & thitung & Sig. & Keterangan \\
\hline Religiusitas & Profesionalisme & $\mathrm{H} 1$ & + & 0.423 & 2.481 & 0.018 & Signifikan \\
\hline Religiusitas & Independensi & $\mathrm{H} 2$ & + & 0,289 & 1.355 & 0.185 & $\begin{array}{c}\text { Tidak } \\
\text { signifikan }\end{array}$ \\
\hline Profesionalisme & Independensi & $\mathrm{H} 3$ & + & 0,124 & 0.660 & 0.514 & $\begin{array}{c}\text { Tidak } \\
\text { Signifikan }\end{array}$ \\
\hline Religiusitas & Kualitas audit & $\mathrm{H} 4$ & + & 0.171 & 1.986 & 0.055 & $\begin{array}{c}\text { Tidak } \\
\text { signifikan }\end{array}$ \\
\hline Profesionalisme & Kualitas audit & $\mathrm{H} 5$ & + & 0.320 & 4.277 & 0.000 & Signifikan \\
\hline Independensi & Kualitas audit & $\mathrm{H} 6$ & + & 0.262 & 4.047 & 0.000 & Signifikan \\
\hline
\end{tabular}

Sumber: Data diolah. 
Religiusitas Auditor secara langsung berpengaruh positif signifikan terhadap Profesionalisme Auditor. Dengan demikian seseorang yang memiliki sikap religiusitas yang tinggi akan berusaha menjalankan segala perintah Tuhannya dan menjauhi segala larangan-Nya, sehingga seorang auditor akan bertindak secara profesional. Seorang akuntan publik yang profesional harus memenuhi tanggungjwabnya terhadap masyarakat, klien termasuk rekan seprofesi untuk berperilaku semestinya dan mendasarkan pada tingkat religiusitas yang baik.

Religiusitas Auditor secara langsung tidak berpengaruh signifikan terhadap Independensi Auditor. Hasil penelitian ini membuktikan bahwa independensi auditor bukan dipengaruhi oleh religiusitasnya, tetapi dipengaruhi oleh sikap mental yang dimiliki auditor untuk tidak memihak dalam melakukan audit, karena auditor melaksanakan pekerjaannya untuk kepentingan umum. Sikap mental inilah yang akan menjadikan masyarakat percaya pada profesi akuntan publik.

Profesionalisme Auditor secara langsung tidak berpengaruh signifikan terhadap Independensi Auditor. Hal ini membuktikan bahwa independensi auditor bukan karena tingkat profesionalisme nya, akan tetapi mengedepankan pada bagaimana menjaga tingkat independensi agar tetap sesuai dengan jalur yang seharusnya dan sikap independen menjadi syarat mutlak yang harus dimiliki oleh auditor.

Religiusitas Auditor secara langsung tidak terbukti berpengaruh signifikan terhadap Kualitas Audit. Religisuitas menggambarkan sejauh mana individu berkomitmen untuk agama dan ajaran-ajaran yang ada di dalamnnya, dapat mempengaruhi standar moral seseorang, sehingga dapat memberikan kontrbusi terhadap idealisme seseorang. Namun demikian, hasil penelitian ini tidak dapat membuktikan bahwa auditor yang memiliki tingkat religiusitas tinggi untuk menghasilkan kualitas audit yang lebih baik.

Profesionalisme Auditor secara langsung berpengaruh positif signifikan terhadap kualitas audit. Hal ini menunjukkan bahwa seorang akuntan publik yang profesional harus memenuhi tanggungjwabnya terhadap masyarakat, klien termasuk rekan seprofesi untuk berperilaku semestinya. Hubungan dengan sesama profesi adalah menggunakan ikatan profesi sebagai acuan, termasuk didalamnya organisasi formal dan kelompok kolega informal sebagai ide utama dalam pekerjaan. Melalui ikatan profesi ini para profesional membangun kesadaran profesional. Adanya berbagai masukan akan menambah akumulasi pengetahuan auditor sehingga dapat membuat perencanaan dan pertimbangan dalam proses pengauditan lebih baik, sehingga dampaknya hasil audit yang dihasilkan akan berkualitas. Hasil ini mendukung penelitian Raviyani (2012), Subianto (2016), Mayangsari (2013), Futri dan Juliarsa (2014), yang menyatakan bahwa profesionalisme auditor berpengaruh positif terhadap kualitas audit.

Independensi auditor secara langsung berpengaruh positif signifikan terhadap Kualitas Audit. Hal ini menunjukkan bahwa seorang auditor yang memiliki sikap independensi akan meningkatkan kualitas audit, karena dalam menjalankan tugasnya sesuai dengan peraturan yang berlaku dan tanpa tekanan atau pengaruh dari klien. Jika auditor bersikap netral maka laporan audit yang dihasilkan akan sesuai dengan kenyataan yang ada, sehingga dapat digunakan sebagai dasar pengambilan keputusan. Hasil ini mendukung penelitian Kurnia, Khomsiyah, \& Sofie (2014), Susilawati dan Yuzi (2013), serta Pratistha dan Widhiyani (2014) yang menyatakan independensi auditor mempunyai pengaruh positif terhadap kualitas audit. 
Mengingat adanya adanya variabel mediasi atau intervening maka terdapat adanya pengaruh tidak langsung. Hasil penelitan menunjukkan bahwa profesionalisme dan independensi auditor tidak terbukti memediasi hubungan variabel religiusitas terhadap kualitas audit, dengan nilai P-value Sobel Test sebesar 0,1411 yaitu nilai lebih besar dari 0.05. Selanjutnya, hanya profesionalisme auditor yang mampu memediasi hubungan religiusitas terhadap kualitas audit, dengan nila $P$-value sebesar 0.034 . Hal ini mengindikasikan bahwa religiusitas secara tidak langsung melalui profesionalisme berpengaruh signifikan terhadap kuaitas audit. Selanjutnya untuk variabel religiusitas melalui independensi terhadap kualitas audit tidak signifikan, dengan nilai P-value sebesar 0,263. Demikian juga pengaruh tidak langsung untuk variabel religiusitas terhadap kualitas audit dengan profesionalisme sebagai mediator tidak signifikan dengan nilai $\mathrm{P}$-value sebesar 0.2796. Sedangkan variabel profesionalisme auditor secara tidak langsung melalui indepensi tidak berpengauh terhadap kuaitas audit.

\section{KESIMPULAN}

Pengujian secara langsung menunjukkan bahwa hanya profesionalisme auditor dan independensi auditor yang terbukti secara langsung berpengaruh positif terhadap kualitas audit. Hal ini menunjukkan bahwa profesionalisme dan independensi merupakan faktor yang sangat penting dalam pemberian opini audit, sehingga akan berdampak terhadap kualitas audit yang dihasilkan. Sedangkan untuk variabel religiusitas tidak cukup bukti berpengaruh positif terhadap kualitas audit. Pengaruh tidak langsung menunjukkan bahwa profesionalisme auditor dan independensi auditor tidak terbukti secara empiris mempengaruhi hubungan religiusitas dengan kualitas audit. Artinya bahwa kualitas audit seorang auditor dipengaruhi secara parsial oleh profesionalisme dan independensi, bukan dipengaruhi oleh religiusitas melalui profesionalisme dan independensi. Meskipun demikian, religiusitas secara tidak langsung melalui profesionalisme auditor berpengaruh signifikan terhadap kualitas audit. Hal ini menunjukkan bahwa religiusitas auditor dapat mempengaruhi kualitas audit apabila auditor memiliki jiwa profesional dalam melakukan audit yang akan berdampak terhadap kualitas audit.

Perlunya evaluasi terhadap variabel lain yang dapat mempengaruhi kualitas audit dengan meningkatkan profesionalitas dan independensi auditor. Hal ini bertujuan untuk menghasilkan kualitas audit yang baik dalam hal mengungkapkan laporan keuangan. Langkah yang dapat dilakukan adalah dengan mengikuti perkembangan audit terbaru agar adaptif terhadap perubahan kebijakan dan perkembangan yang ada. Hasil penelitian ini hanya menggambarkan auditor yang berada di kota Semarang, sehingga perlu menambahkan jumlah sampel dengan melibatkan auditor di propinsi yang lain. Sedangkan untuk variabel penelitian perlu dikaji lebih lanjut agar hasil penelitian ini lebih baik, karena masih banyak faktor yang dapat mempengaruhi kualitas audit.

\section{DAFTAR PUSTAKA}

Arens, A. M. et all. 2011. Auditing dan Jasa Assurance. Jakarta : Erlangga.

Futri, P. S, and Juliarsa, G. 2014. Pengaruh Independensi, Profesionalisme, Tingkat Pendidikan, Etika Profesi, Pengalaman, dan Kepuasan Kerja Auditor terhadap Kualitas Audit pada Kantor Akuntan Publik di Bali. E-Jurnal Akuntansi Universitas Udayana, 8(1), pp. 41-58. 
Religiusitas Auditor terhadap Kualitas Auditor Eskternal...

Winarsih

Ghozali, I. 2011. Aplikasi Analisis Multivariate dengan program IMB SPSS 19. Edisi Kelim. Semarang: Universitas Diponegoro.

Hastuti, E. W. 2014. Pengaruh Moral Reasoning, Religiusitas, Independensi, dan Skeptisisma Profesional terhadap Kualitas Audit Auditor Pemerintah. Yogyakarta: Universitas Gadjah Mada.

Hutahahean, M. U. and Hasnawati. 2015. Pengaruh Gender, Religiusitas, dan Prestasi Belajar terhadap Perilaku Etis Akuntan Masa Depan. e-Journal Akuntansi Trisakti, 2 (1), pp.49-66.

Kharismatuti, N. and Hadiprajitno, P. B. 2012. Pengaruh Kompetensi dan Independensi terhadap Kualitas Audit dengan Etika Auditor Sebagai Variabel Moderasi. Diponegoro Journal of Accounting, 1(1), pp. 1-10.

Kurnia, W., Khomsiyah and Sofie. 2014. Pengaruh Kompetensi, Independensi, Tekanan Waktu, dan Etika Auditor terhadap Kualitas Audit. e-Journal Akuntansi Fakultas Ekonomi Universitas Trisakti, 1(2), pp. 49-67.

Mayangsari, S. 2003. Pengaruh Keahlian dan Independensi terhadap Pendapat Audit: Sebuah Kuasieksperimen. Jurnal Riset Akuntan Indonesia, 6(1), pp. 1-22.

Mayasari, I. 2013. Pengaruh Profesionalisme Auditor dan Masa Perikatan Audit terhadap Kualitas Audit. Skripsi Universitas Komputer Indonesia.

Pamungkas, I. D. 2014. Pengaruh Religiusutas dan Rasionalisasi dalam Mencegah dan Mendeteksi Kecenderungan Kecurangan Akuntansi. Jurnal Ekonomi dan Bisnis, 15(2), pp.48-59.

Pratistha, K. D. and Widhiyani, N. L. 2014. Pengaruh Independensi Auditor dan Besaran Fee Audit terhadap Kualitas Proses Audit. E-Jurnal Akuntansi Universitas Udayana, 6(3), pp. 419-428.

Rahardjo, K. M. 2012. Pengaruh Pengalaman Kerja, Independensi Objektifitas, Integritas, Kompetensi, dan Komitmen Organisasi Hasil Audit. Diponegoro Journal of Accounting, 1(2), pp. 1-11.

Reviyani, E. 2012. Pengaruh Kompetensi Auditor dan Profesionalisme Auditor terhadap Kualitas Audit. Skripsi Universitas Lampung.

Sekaran, U. 2006. Research Methods For Business. Jakarta: Salemba Empat.

Sukriah, I., Akram., and Inapty, B. A. 2009. Pengaruh Pengalaman Kerja, Independensi, Objektivitas, Integritas, dan Kompetensi terhadap Kualitas Hasil Pemeriksaan. Simposium Nasional Akuntansi XII, Palembang .

Susilawati, S. 2014. Pengaruh Profesionalisme dan Independensi Auditor Internal terhadap Kualitas Audit: Studi pada Inspektorat Propinsi Jawa Barat. Jurnal Etikonomi, 13(2), pp.190-210.

Tjun, L. T., Marpaung, E. I., and Setiawan, S. 2012. Pengaruh Kompetensi dan Independensi Auditor Terhadap Kualitas Audit. Jurnal Akuntansi, 4(1), pp. 33-56 .

Wardana, M. A., and Ariyanto, D. 2016. Pengaruh Gaya Kepemimpinan Transformasional, Objektivitas, Integritas, dan Etika Auditor terhadap Kualitas Audit. E-Jurnal Akuntansi Universitas Udayana, 14(2), pp.948-976. 